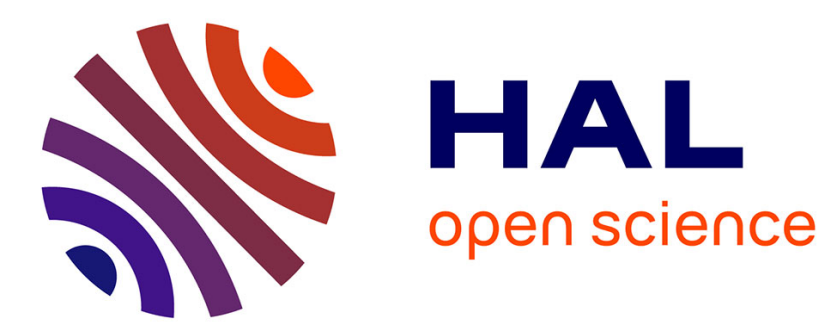

\title{
Highly Qualified Women in the 'New Europe': Territorial Sex Segregation
}

Judith Glover

\section{To cite this version:}

Judith Glover. Highly Qualified Women in the 'New Europe': Territorial Sex Segregation. European Journal of Industrial Relations, 2005, 11 (2), pp.231-245. 10.1177/0959680105053965 . hal-00570939

\section{HAL Id: hal-00570939 \\ https://hal.science/hal-00570939}

Submitted on 1 Mar 2011

HAL is a multi-disciplinary open access archive for the deposit and dissemination of scientific research documents, whether they are published or not. The documents may come from teaching and research institutions in France or abroad, or from public or private research centers.
L'archive ouverte pluridisciplinaire HAL, est destinée au dépôt et à la diffusion de documents scientifiques de niveau recherche, publiés ou non, émanant des établissements d'enseignement et de recherche français ou étrangers, des laboratoires publics ou privés. 


\title{
Judith Glover
}

Roehampton University, UK

\section{Highly Qualified Women in the 'New Europe': Territorial Sex Segregation}

\begin{abstract}
The proportion of women in highly qualified scientific employment in central and eastern Europe and the Baltic States (CEEC-10) is higher than in western Europe. However, this relatively high representation is counteracted by unequal access to resources. This is illustrated by a new measure, the 'honeypot indicator'. The focus of the EU 'Lisbon strategy' summit on increasing overall numbers of scientists does little to address the key issues of retention and advancement. Although social closure mechanisms may undermine the employment prospects of highly qualified women, the conclusion is that the accession of the CEEC-10 to the 'mainstreaming' of equal opportunities proclaimed by the European Union provides the best hope of improvement for their employment prospects.
\end{abstract}

\section{Introduction and Background}

The focus of this article is on highly qualified women in the CEEC-10, defined here as the eight countries that joined the European Union (EU) in May 2004 (Czech Republic, Estonia, Hungary, Latvia, Lithuania, Poland, Slovakia and Slovenia) and the two scheduled to join in 2007 (Bulgaria and Romania). High qualifications are defined as at least a first degree in a range of areas of knowledge, from the natural sciences to the humanities, according to ISCED 5 and 6 (UNESCO, 1997). The occupational title 'researchers' is the category used in the OECD Frascati Manual (OECD, 2002). They are defined in the following terms: 'researchers are professionals engaged in the conception or creation of new knowledge, products, processes, methods and systems and also in the management of the projects concerned'. In International Labour Organization (ILO) terms, they are classified as ISCO 2 Professionals: 'occupations whose main tasks require a high level of professional knowledge and experience in the fields of physical and life sciences, or social sciences and humanities'. However, the term 'women scientists' is interchangeably and routinely used in European Commission 
documents to cover this group of highly qualified women; this article follows suit.

The definition of science used by the Commission and most EU countries (the UK is an exception) is broad, including all areas of organized knowledge: the arts, humanities, social sciences, natural sciences, engineering, and various technologies. This broader concept is the Wissenschaft definition of science. Although the terminology is not always consistent, Commission literature tends to use the label 'science and technology' when applying this broad definition; the natural sciences and associated technological fields tend to be referred to as 'science and engineering'. This article focuses on the broader field, although distinctions are made in the discussion of access to resources in different fields.

In March 2000, the EU Lisbon summit launched a European Research Area (ERA) as a means to the goal of making Europe 'the most competitive and dynamic knowledge-based economy in the world'. The target was to increase expenditure on research to 3 percent of GDP, with a target of 700,000 new research and development (R\&D) specialists by 2010. The European Commission recently reported that women are better represented in the highly qualified scientific workforce in the CEEC-10 than in the EU-15, accounting for 38 percent of the scientific workforce (EC, 2003a). The proportion ranges from 52 percent in Latvia to 27 percent in the Czech Republic, as against an average for the EU-15 of 27 percent.

The argument in this article is that there is, however, little evidence of the mainstreaming of gender equality for women scientists in the CEEC10, and this absence puts at risk the ERA aim of building the scientific human resources of Europe. While the number of women scientists is a positive sign for the ERA in its bid to increase capacity, the conditions under which they are working are likely to undermine that capacity.

The high numbers of CEEC-10 women scientists can be seen as a residue of the communist regime, where women and men had equal rights to and indeed obligations of full-time employment, as well as equal access to education. Childcare facilities, legal protection, and various forms of support for working mothers were supplied by the state. In the communist era, public-sector science and technology were privileged in resource terms and men were well represented there (EC, 2003a). A particular effect of the transition between communism and a market economy was that state funding allocated to science declined sharply, in part as a consequence of the disappearance of the military and associated industries. Unemployment followed, with a consequent brain drain, primarily of men. Although this change affected both women and men scientists, women were left in a more vulnerable situation (EC, 2003a). With the privileging of the market economy, public-sector science became low status and particularly poorly resourced. Currently, its personnel are 
mainly women. Those men who remain in the public sector tend to be older (probably because older men tend to be unattractive to, and unattracted by, the risky new environment of the market economy). They are also typically employed in privileged positions: there is strong evidence of vertical sex segregation in higher education employment (EC, 2003b), as well as more generally between 'researcher' and 'technician' posts (Eurostat, 2004). This segregation is explored in a later section. The historical background and the gender effects as the funding regime changed are presented schematically in Table 1 .

The main focus of this article is not the long-debated and largely unresolved issue of whether high rates of feminization bring about the low status of an occupation or field, or whether women join an occupation that is already of low status, although Table 1 throws some light on this. The 'chain of events' here is that when public-sector science was well funded and enjoyed high status, the numbers of men were high. When funding was drastically reduced, status fell and opportunities shifted to the private sector; the numbers of men in publicly funded science fell, bearing out the theory of gender queues proposed by Reskin and Roos (1990). Thus, the large numbers of women in scientific employment in the post-communist era is associated with low status, but it does not appear to have been its cause.

\section{The European Research Area}

The ERA, first mooted at the Lisbon Summit in 2000 and elaborated by the European Commission, reflects a concern that the gap between

TABLE 1. The Funding of Science in the Move from Communism to a Market Economy and the Representation of Women and Men

\begin{tabular}{llll}
\hline Communist era & Transition era & \multicolumn{2}{c}{ Market economy } \\
\hline $\begin{array}{l}\text { Natural sciences } \\
\text { well resourced; } \\
\text { higher education } \\
\text { and (public-sector) }\end{array}$ & $\begin{array}{l}\text { Science poorly } \\
\text { resourced, loses } \\
\text { status }\end{array}$ & $\begin{array}{l}\text { Public-sector } \\
\text { science poorly } \\
\text { resourced }\end{array}$ & $\begin{array}{l}\text { Private-sector } \\
\text { science better } \\
\text { resourced, with } \\
\text { increasingly good } \\
\text { status }\end{array}$ \\
$\begin{array}{l}\text { Large numbers of } \\
\text { men }\end{array}$ & $\begin{array}{l}\text { Declining } \\
\text { numbers of men }\end{array}$ & $\begin{array}{l}\text { Low numbers of } \\
\text { men, high numbers } \\
\text { of women; older } \\
\text { men in higher } \\
\text { positions }\end{array}$ & $\begin{array}{l}\text { High numbers of } \\
\text { numbers of women }\end{array}$ \\
& & &
\end{tabular}


European funding of R\&D and that of the US and Japan has been widening (EC, 2003c: 4). The Commission attributes this to low investment by the private sector, which in Europe provides only 56 percent of the total financing of research, as against more than two-thirds in the US and Japan (EC, 2003d). The EU as a whole spent only 1.94 percent of GDP on R\&D in 2000 , compared to 2.80 percent in the USA and 2.98 percent in Japan. Moreover, this 'investment gap' has widened rapidly since the mid-1990s. In terms of purchasing power, the EU-US divide increased markedly, from €43 billion in 1994 to $€ 83$ billion in 2000; and although the EU produces a larger number of graduates and $\mathrm{PhDs}$ in science and technology than the US and Japan, it employs fewer researchers: 5.4 per 1000 of the labour force, against 8.7 in the US and 9.7 in Japan (EC, 2003d). This implies a poor return on the costs of education. There is also specific concern about a slowdown in growth: the growth rates in the EU-15 of both overall investment and overall performance in the knowledge-based economy were markedly lower in 2000-01 than during the second half of the 1990s (EC, 2003d).

A key aspect of the ERA is the expectation set out in 2002 at the European Council in Barcelona that all countries should spend 3 percent of GDP on R\&D by 2010 (EC, 2003c). Several of the EU-15 are close to this, although some, particularly the Mediterranean countries, are further away. However, many of the new member states are far from achieving this target: Latvia spends only 0.48 percent (EC, 2003a). The 3-percent target includes a clear emphasis on private-sector funding: two-thirds is expected to come from this sector. I will come back to this point, arguing that this is a structural aspect that undermines women's employment prospects.

The ERA contains two main aims relating to women scientists. The first can be seen as explicitly related to the bottom line of productivity, while the second, sometimes referred to as the 'democratic principle' (EC, 2003e), is concerned with the moral arguments for equal opportunities.

The first of these addresses women as a major untapped pool that could bring about the intended growth in the knowledge economy. 'Women are an under-exploited resource in research for the European Union and have a huge potential for the future of research in Europe' (EC, 2004: 47). Commissioner for Research Philippe Busquin specifically linked the employment of women scientists to the 3-percent target and the related 2010 objective of a further 700,000 researchers, referring to retention and advancement as well as recruitment (and thus implicitly acknowledging the 'democratic principle' of equal opportunities): 'we will not reach the 3 percent objective if we fail to recruit, retain and promote the women who constitute an important share of Europe's pool of trained scientists' (EC, 2003b: 5). 
A second aspect of the ERA that concerns us here is the stated bid to make research more attractive to underrepresented groups, particularly women, and to increase their retention (EC, 2003a: 11) by providing 'favourable career development prospects' and 'mainstreaming gender equality' (EC, 2003a: 12). The basis of many of the ERA activities, including the Framework Programmes, is an emphasis on mobility within Europe in order to improve the knowledge and skills base (EC, 2001). I return to this briefly in the concluding discussion.

\section{Territorial Sex Segregation}

The term 'territorial sex segregation' was used by Rossiter (1982, 1995) in her studies of women scientists in the US in the 19th and 20th centuries. She primarily uses it to describe the way in which highly qualified women were employed in low-status and low-paid enclaves within scientific fields. In a broad sense, this means the same as horizontal segregation: both concepts seek to describe and measure the proportions of women and men in sub-occupations, occupations, fields, and sectors. In this article, I prefer the term 'territorial' to 'horizontal' for two reasons. The first is simply an issue of semantics: the term itself is more intuitive and for teaching purposes students appear to understand it readily. A second reason relates more to theory: 'territorial segregation' can be used rather more explicitly to designate different levels of spatiality. The emphasis on borders (and thus inclusion and exclusion) draws attention to the existence of enclaves in a way that the term 'horizontal' does not. It is thus particularly apt when discussing the theoretical perspective of social closure as a possible explanation of women's employment patterns; I refer to this briefly in the concluding discussion.

Within countries, different levels of territorial segregation can be identified: broad occupations, industries and fields of expertise, sectors and sub-occupations (small fields within occupations). The occupational level is perhaps the most common way that horizontal (territorial) segregation is used; following Hakim (1979), calculations are typically made, using standardized occupational typologies, of over- and underrepresentation of women and men in broad occupational groups. Also of interest is segregation in broad fields of expertise: women concentrated in medical, agricultural and social sciences. In sectoral segregation, the key distinction is between the public sector, typically divided in the available European statistics into government and higher education employment, and the private sector, referred to as the business and enterprise sector. The sub-occupational level draws attention to the phenomenon of an occupation that does not appear to be sex segregated in aggregate terms, but can be shown to have high levels of sex segregation within it. 
These 'niches' can show very different proportions of women and men. Clear examples here are medicine and law (Crompton and Harris, 1998; Epstein et al., 1998; Riska and Wegar, 1993; Schultz and Shaw, 2003). The extent to which these different levels can be operationalized depends, of course, upon the availability of data. For example, it would be particularly interesting to know the representation of women and men in subfields that the Commission identifies as showing clear growth, such as information and communication technologies (ICTs), nanotechnology, biotechnology and pharmaceuticals (EC, 2004). Information at a subfield level is not readily available, since the classification of fields of science, the Frascati Manual (OECD, 2002), does not currently disaggregate to this level of detail.

Although the main focus in this article is on broad fields of expertise and sectors, vertical sex segregation is also examined in the following section, which deals with the current employment conditions for women scientists in the CEEC- 10 .

\section{Current Conditions: Vertical Sex Segregation}

Available European data on vertical sex segregation relate almost exclusively to employment in higher education. The countries under scrutiny here show that men are on average three times more likely than women to be in 'Grade A' positions (the category of 'full professor'), and five times more likely in the Czech Republic, Lithuania, and Slovakia. The average figure is similar to the EU-15 (EC, 2003b: 64); I briefly return to the broad European similarities at the end of this article. There is a need for caution about the figures, since the definitions of different grades vary to some degree cross-nationally. These data come from the Helsinki Group of Statistical Correspondents, a group convened by the Women in Science Unit of the Science and Society Directorate of the European Commission, and composed of senior civil servants responsible for women and science in their country, together with statisticians nominated by each national statistics agency. ${ }^{1}$

A second, more general measure of vertical sex segregation is the Eurostat distinction between 'researcher' and 'technician' (OECD, 2002). Eurostat (2004) shows that women are considerably more likely than men to be in technician jobs, despite being similarly qualified. This picture of overqualification is also noted for women in science, engineering, and technology in the UK (Fielding et al., 1997) and the US (Etzkowitz et al., 2000; Rossiter, 1982, 1995).

One consequence of vertical segregation is, of course, the pay gap. Data on pay are currently exceptionally sparse, but the ILO Laborsta database of selected occupations is one source. From this, I have selected two 
science and engineering occupations (here using the narrower definition of science, as explained earlier): a mathematics lecturer in higher education, largely to be found in the public sector, and a chemical engineer, more likely to be in the private sector, particularly in view of the increase in the number of privately funded universities in the CEE and the Baltic States (EC, 2003c: 56). This shift of employment to the private sector appears to be particularly significant in Poland, the Czech Republic and Hungary.

These data need to be treated with some caution, in particular because there is no firm evidence that these occupations are representative of the public and private sectors, respectively. Nevertheless, it seems reasonable to treat these as indicative, until more systematic data become available. There is evidence of a gender pay gap, sometimes marked, in both of these occupations, though the size of this gap is greater in some countries in the public sector and in others, in the private (see Table 2). In terms of overall pay levels, however, the occupation that is more likely to be in the private sector (chemical engineer) pays in almost all cases consistently better than the public-sector higher education job. This is an important point, since as discussed later, women are considerably less likely to be in private-sector employment than men. The differences between earnings in the EU-15 and CEEC-10 are not a focus of this article, but the average earnings for the two selected occupations in the lowest-paid EU-15 country, Portugal, have nevertheless been included. These show a similar pattern of inequality, though at a far higher level of income.

It is not a main purpose of this article to address the evolution of the pay gap from communism to the market economy; this is particularly difficult to establish because of patchy data availability and possible

TABLE 2. Women's and Men's Average Monthly Earnings in ILO Occupations 145 and 52, 2001

\begin{tabular}{lccccc}
\hline Country & \multicolumn{2}{c}{ HE mathematics lecturer } & & \multicolumn{2}{c}{ Chemical engineer } \\
\cline { 2 - 3 } \cline { 6 - 6 } \cline { 6 - 6 } & Women (\% of male) & Men & & Women (\% of male) & Men \\
\hline Latvia & $€ 358(81)$ & $€ 439$ & & $€ 359(80)$ & $€ 450$ \\
Lithuania & $€ 373(75)$ & $€ 494$ & & $€ 461(61)$ & $€ 759$ \\
Poland & $€ 544(79)$ & $€ 688$ & & $€ 671(85)$ & $€ 786$ \\
Romania & $€ 173(77)$ & $€ 223$ & & $€ 197(83)$ & $€ 238$ \\
Slovakia & $€ 294(91)$ & $€ 322$ & & $€ 409(77)$ & $€ 533$ \\
Portugal & $€ 1309(98)$ & $€ 1341$ & & $€ 1558(72)$ & $€ 2167$ \\
\hline
\end{tabular}

Note: ${ }^{a} 2000$.

Source: calculated from ILO Laborsta DataBase (www.laborsta.ilo.org) for countries that disaggregate data by sex. 
discrepancies between communist and post-communist data-collection systems and techniques. Nevertheless, the ILO database gives some limited indication of more recent trends. The higher education mathematics teacher is the only relevant occupation for which time-series data are available and only for two countries: Latvia and Romania (see Table 3 ). These take us from the end of the transition period to the market economy, showing that the pay gap in these two countries is widening over time. This provides further (albeit limited) evidence that women's employment opportunities in the market economy are a matter for concern.

This leads to a consideration of contemporary territorial sex segregation in scientific employment at sectoral and field levels in the market economy. The link with gross expenditure on research and development (GERD) provides new evidence of the consequences of sex segregation in terms of the distribution of resources.

\section{Territorial Sex Segregation: Sectors and Fields}

Turning first to the sectoral level: 47 percent of GERD in the CEEC-10 goes to the business and enterprise sector, with the remainder being split approximately equally between the government and higher education sectors (EC, 2003a: 79). Yet, 84 percent of women researchers in these countries work in the latter two sectors (EC, 2003a: Table 3.1). Furthermore, the prospects for women look set to deteriorate, since the sectors where women are concentrated show the greatest decrease in resources. It is a particularly important point that the 3-percent target in the ERA specifies that two-thirds of $R \& D$ spending should be in the private sector, where women are least well represented. Furthermore, there is evidence from Commission statistics that the representation of women researchers in the private sector is decreasing, from 31 percent in 1999 to 25 percent in 2002 (calculated from http://europa.eu.int/comm/research/sciencesociety/women/wssi/downstat_en.html). Data need to be treated with

TABLE 3. Women's Pay as a Percentage of Men's in ILO Occupation 145, Latvia and Romania, 1997-2001

\begin{tabular}{lccccc}
\hline & 1997 & 1998 & 1999 & 2000 & 2001 \\
\hline Latvia & 91 & 91 & 87 & 81 & 81 \\
Romania & 86 & 84 & 76 & 84 & 77 \\
\hline
\end{tabular}

Source: calculated from ILO Laborsta DataBase (www.laborsta.ilo.org) for countries that disaggregate data by sex. 
caution here, however, since the publicly available time series covers only these four years; it is possible that 1999 is a 'blip'.

A more detailed disaggregation shows that women tend to be concentrated in those fields of expertise where resources in the form of infrastructure, equipment, and pay are least available. The highest level of resourcing is found in science and engineering (the narrow definition of the knowledge economy, as shown earlier) and the lowest level is in the social sciences, arts, and humanities. In the countries examined here, 23 percent of researchers in engineering are women, and the annual per capita R\&D expenditure for researchers in engineering is $€ 18,500 ; 43$ percent of social science researchers are women, yet the R\&D per capita expenditure here is $€ 7200$ (EC, 2003c: Tables 3.5, 3.7). This effect is compounded by the sectoral location of these fields: social sciences are largely concentrated in the poorly resourced higher education sector, while engineering is located mainly in the relatively well-resourced business and enterprise sector.

The consequences of these forms of territorial segregation can be explored in terms of access to resources. A new measure, the 'honeypot indicator', has been developed by statisticians in the Commission's Science and Society Directorate and by Eurostat (EC, 2003c; Eurostat, 2004). This establishes the extent to which women miss out on available resources (infrastructure, equipment, and pay) by measuring the relationship between GERD and the concentrations of women and men in both sectors and fields of R\&D. It is based on two measures of per capita expenditure for women: an expected value and an observed value. The expected value is calculated by dividing total $\mathrm{R} \& \mathrm{D}$ expenditure by the overall proportion of women scientists. The observed value is calculated by dividing the amount of R\&D expenditure in each sector or field of science by the proportion of women in that sector or field, and then summing these amounts. The 'honeypot' score is the difference (the observed minus the expected) between these values expressed as a percentage of the expected value.

As an example, women researchers in the Czech Republic miss out on around 16 percent of the per capita share of $\mathrm{R} \& \mathrm{D}$ expenditure. Using Eurostat (2004) figures, all things being equal, women researchers in the Czech Republic could be expected to attract $€ 223.3$ million of GERD. However, they are only observed to attract $€ 186.7$ million. The difference between the expected and observed amounts, expressed as a percentage of the expected value, results in a sector score of 16.4 percent.

\section{Discussion and Conclusion}

At first sight, the 'women and science' issue in the EU-15 (persistently low representation of women and evidence of vertical segregation in 
higher education employment, as documented in EC [2000, 2003e]) appears to be less serious in the CEEC-10, since there the representation of women scientists is high. However, a more detailed examination, provided previously, suggests that here too, highly qualified women are losing out on new opportunities in the European knowledge economy.

To summarize, the available evidence reveals a picture of vertical sex segregation, a consistent pay gap and territorial sex segregation. In relation to the latter, this relates to both sectors and fields, and possibly an interaction between the two. Women are heavily concentrated in public-sector science, but the majority of funding goes to the private sector; and indeed, the ERA insists that two-thirds of GERD should be in this sector. In all of these countries, the growing and relatively wellresourced business and enterprise sector has the lowest representation of women. The least well-resourced (and increasingly badly resourced) sectors (government-funded science and higher education employment) have the highest representation of women. There is a gendered allocation of resources. This picture has caused the Commission to conclude as follows: 'women are being used as a kind of secondary human resource ... because the reward system is no longer sufficiently attractive [to men]' (EC, 2003a: 84).

Why, since the ERA emphasizes the private sector and this is the main target of funding, do women not switch to those sectors that offer the best opportunities? The Commission acknowledges women's agency: their location in the more stable, but poorly paid, publicly funded science may be a strategy of women 'choosing to work here in order to support their families with at least one stable income in the new competitive and risky environment' (EC, 2003a: 77). At a structural level, a key feature of the post-communist era is a lack of appropriate welfare policies that would ease the relationship between domestic and working lives. This particularly affects women because the domestic division of labour remains as traditional in the market economy as it was under communism, and possibly even more so (EC, 2003a; Kocourková, 2002; Lobodzinska, 1995; Pascall and Manning, 2000).

Social closure theory has played a particularly important role in explaining women's employment patterns in the professions, both historically and contemporaneously. It has been used particularly effectively by Witz (1992) to explain the history of women's exclusion from medicine in the UK. She concludes that dominant groups in occupations or sectors that are growing in status, or seeking to professionalize, can sustain their position by constructing exclusionary boundaries with related or adjacent occupations. This creates for particular social groups distinct spheres of competence that relate to different levels of prestige. Women are not excluded completely from occupations or fields, since to do so would be to deny their qualifications, but they are contained in 
particular enclaves. This process, which I refer to as 'contained inclusion' (and which Witz (1992) calls 'demarcationary closure'), denotes the incorporation of women into sectors or occupations in a particular set of circumstances and occupational locations, typically of low status and low pay and, importantly, in 'behind-the-scenes' positions that lack visibility.

Applying this theoretical framework to the situation of women scientists in the CEEC-10, it can be expected that private-sector employment will be problematic for women, since it has become the destination of choice for men scientists. It is likely that women will occupy a limited range of positions in the developing private sector, illustrating a particular type of territorial segregation, that of 'contained inclusion' in subfields within broad areas. This prediction can be related to the work of Rossiter $(1982,1995)$, who describes how the rapidly growing biological sciences in the mid-20th-century US required pre-computer taxonomic (cataloguing) work. Highly qualified and largely overqualified women typically found work here. Since their numbers were often high, a calculation of their numerical representation within the biological sciences would have shown a 'good' result. Yet, the reality, as in the CEEC-10, was that their pay and prospects were poor, since highly qualified women worked primarily as technicians. As we have seen, evidence from the CEEC-10 reveals the same pattern.

As noted earlier, in its presentation of the ERA, the Commission placed considerable emphasis on mobility within Europe as a means to improve the knowledge and skills base of the knowledge economy (EC, 2001). This policy is in line with the traditional view of the 'itinerant' scientist (Glaser, 1964). In line with this objective, grants for mobility within Europe have increased markedly, and the Commission has developed information networks such as the Researcher's Mobility Portal. How will this affect women? Although we could make an educated guess, given the well-documented relationship between women's employment and domestic activities, there is to date only patchy evidence here. On the basis of a UK-Italy comparison, Ackers et al. (2003) conclude that while women are more likely than men to study outside their home country as undergraduates through the ERASMUS programme, this mobility declines at the postgraduate level. Thus the 'brain drain' may be a primarily male phenomenon, and this could be a further factor in women 'propping up the R\&D remains that are of little interest to men' (EC, 2003a: 84).

Although the representation of women scientists in the CEEC-10 is higher than in the EU-15, similar characteristics are found in both regions, as a series of Commission reports has shown (EC, 2000, 2003d). The representation of women in private-sector research in the EU-15 is considerably lower than that of men: in the 10 countries that provide 
disaggregated data, women make up between 9 and 28 percent of privatesector researchers, with an average of 15 percent; in Germany, with by far the largest number of private-sector researchers, the proportion is 9.6 percent (EC, 2003e: 15-16). Because of women's concentration in other sectors, the 'honeypot indicator' calculation shows women scientists losing out on 24 percent of the per capita share of $\mathrm{R} \& \mathrm{D}$ expenditure in Spain, 20 percent in Finland, 16 percent in Belgium, 10 percent in Denmark, and 9 percent in Germany (Eurostat, 2004: Table 2). In higher education, there is clear vertical sex segregation, measured by the percentage of women who are 'full professors': this ranges from 5 percent in the Netherlands to 18 percent in Finland (EC, 2000).

All EU-15 and CEEC-10 countries show poor female retention rates, from education through to employment (EC, 2000, 2003d). This implies that women are initially interested in natural sciences, but that subsequently this interest wanes. In the UK, calculations from the 2001 Labour Force Survey show that at any one time 50,000 women with science, engineering, and technology degrees were not in paid work; of these, only half can be expected to return to paid work, of whom only a third will take science-based jobs, often in 'associate professional' technician jobs for which they are overqualified (DTI, 2002).

These figures imply that it is inadequate to focus on the numbers of women, without regard to the conditions, in terms of structure and culture, under which they work. I have argued elsewhere (Glover, 2000, 2001) that a major weakness of the many debates and subsequent campaigns to improve the 'women and science' situation is a concentration on increasing the numbers of women scientists to some point at which it is thought that a critical mass will have been achieved. Thus women themselves are the focus of these campaigns, with the institutional (cultural) aspects of scientific education and scientific employment typically receiving little scrutiny. The emphasis on critical mass is a similar problem with the ERA. The target refers to numbers, in which respect the CEEC-10 is doing rather better than the EU-15. However, as I have shown in this article, once the detail of this overall picture is examined, there is considerable evidence that the 'women and science' problem has not been resolved. The relatively high numbers are largely a residue of structural and institutional aspects of the communist era, and their significance cannot be interpreted without reference to the conditions under which women work. In the long run, 'contained inclusion' will have economic consequences for the ERA, because the quality of R\&D will suffer as a result of women working for low pay in poor conditions. Another aspect of the ERA, the desire to give highly qualified women 'favourable career prospects' (EC, 2003c), is far from being achieved. Any future 'women and science' policy needs to focus much more on the conditions under which retention and advancement can take place, as well as on increasing recruitment. 
Rees (1998) refers to the need, termed 'visioning', to understand how existing practices, cultures and institutional arrangements disadvantage one sex over the other. The Greenfield Report on employment of women scientists in the UK concluded that there is a need for more research that provides a better understanding of scientific cultures (Greenfield, 2002: 29). Unusually for official reports on the 'women and science problem', the report draws attention to the concept of 'institutionalized sexism'. Greenfield (2002: 29) concludes that 'overt discrimination' is not the prime reason for women not entering scientific careers or drifting away from them. Rather, it is 'the perception and reality of the workplace, coupled with a systematic set of policies and processes that work together to create a culture that excludes or marginalizes women'. Perhaps predictably, the concept of institutionalized sexism did not figure in the government's response to the report, which steered away from examining explanations, preferring to focus on the establishment of a resource centre that would work with science, engineering, and technology employers and professional bodies to identify 'good practice' (DTI, 2003). It is too early to say whether this approach will go beyond the traditional emphasis on increasing numbers.

The argument in this article is that there is as yet little evidence of gender equality for women scientists in the 'New Europe', and that this threatens to undermine the ERA objective of building the scientific human resources of Europe. Thus, the numbers of women scientists appear at first glance to be a positive sign for the ERA in its bid to increase capacity, but the conditions under which they are working are likely to undermine that capacity. The 'bottom line' of productivity is more likely to have firm foundations when it is combined with the 'democratic principle' of equal opportunities; the potential of this relatively 'untapped' pool of highly qualified women might then be realized.

However, if social closure perspectives, briefly introduced above, have at least some explanatory purchase, structural improvements that give priority to retention and advancement issues are unlikely to be successful. The essence of 'contained inclusion' is that it is in the interest of the privileged group to do little or nothing about improving opportunities for the less privileged group. Nevertheless, it seems important to avoid a counsel of despair and possible oversimplification of the issue through reliance on one theoretical perspective only. It seems at least possible to devise certain types of policies that have the potential to circumvent the unwillingness of privileged groups to dismantle occupational boundaries. As Pollert (in this issue, 2005) argues (nevertheless, with caveats about the way that these countries have satisfied EU accession requirements), the accession of the CEEC-10 to the European Union places these countries in the policy context of the mainstreaming of equal opportunities. This may prove to be the best chance for a gradual improvement in women's employment prospects in these countries. 


\section{ACKNOWLEDGEMENT}

An earlier version of this article was presented to the Work, Employment and Society conference, Manchester, September 2004. I acknowledge Colette Fagan's particularly useful comments.

\section{NOTE}

1 The data supplied by this group are available at http://europa.eu.int/comm/ research/science-society/women/wssi/downstat_en.html as the WiS database. Some have been published in EC (2003a, 2003b).

\section{REFERENCES}

Ackers, L., Morano, S. and Turton, I. (2003) Mobility and Excellence in Scientific Labour Markets: The Question of Balanced Growth. Swindon: ESRC.

Crompton, R. and Harris, F. (1998) 'Gender Relations and Employment: The Impact of Occupation', Work, Employment and Society 12: 297-316.

DTI (2002) Maximising Returns to Science, Engineering and Technology Careers. London: DTI.

DTI (2003) A Strategy for Women in Science, Engineering and Technology. London: DTI.

EC (2000) Science Policies in the European Union: Promoting Excellence through Mainstreaming Gender Equality, European Technology Assessment Network (ETAN) 'Women and Science' report. Brussels: EC.

EC (2001) A Mobility Strategy for the ERA, COM(2001)331 Final. Brussels: DG Research.

EC (2003a) Waste of Talents: Turning Private Struggles into Public Issues: Women and Science in the ENWISE Countries. Luxembourg: OOPEC.

EC (2003b) 'She Figures': Women and Science Statistics and Indicators. Brussels: EC.

EC (2003c) Investing in Research: An Action Plan for Europe. Brussels: EC.

EC (2003d) Third European Report on Science E Technology (SET) Indicators. Brussels: DG Research.

EC (2003e) Women in Industrial Research: A Wake Up Call for European Industry. Brussels: EC.

EC (2004) Key Figures 2003-2004: Towards a European Research Area. Brussels: DG Research.

Epstein, C.F., Seron, C., Oglensky, B. and Saute, R. (1998) The Part-Time Paradox: Time Norms, Professional Lives, Family, and Gender. London: Routledge.

Etzkowitz, H., Kemelgor, C. and Uzzi, B. (2000) Athena Unbound: The Advancement of Women in Science and Technology. Cambridge: Cambridge University Press.

Eurostat (2004) 'Women, Science and Technology: Measuring Recent Progress Towards Gender Equality', Statistics in Focus, Theme 9, 6/2004. Luxembourg: Eurostat. 
Fielding, J., Glover, J. and Smeaton, D. (1997) Gender and Science, Engineering and Technology. Swindon: ESRC.

Glaser, B. (1964) Organizational Scientists: Their Professional Careers. Indianapolis, IN: Bobbs-Merrill.

Glover, J. (2000) Women and Scientific Employment. Basingstoke: Macmillan.

Glover, J. (2001) 'Targeting Women: Policy Issues Relating to Women's

Representation in Professional Scientific Employment', Policy Studies 22: 69-81.

Greenfield, S. (2002) SET Fair: A Report on Women in Science, Engineering and Technology. London: DTI.

Hakim, C. (1979) Occupational Segregation, Research Paper 9. London:

Department of Employment.

ILO (1990) ISCO-88: The International Standard Classification of Occupations 1988. Geneva: ILO.

Kocourková, J. (2002) 'Leave Arrangements and Childcare Services in Central Europe: Policies and Practices Before and After the Transition', Community, Work and Family 5: 301-18.

Lobodzinska, B. (1995) Family, Women and Employment in Central-Eastern Europe. Westport, CT: Greenwood Press.

OECD (2002) Proposed Standard Practice for Surveys on Research and Experimental Development: Frascati Manual. Paris: OECD.

Pascall, G. and Manning, N. (2000) 'Gender and Social Policy: Comparing Welfare States in Central and Eastern Europe and the Former Soviet Union', Journal of European Social Policy 10: 240-66.

Pollert, A. (2005) 'Gender, Transformation and Employment in Central Eastern Europe', European Journal of Industrial Relations 11(2): 213-230.

Rees, T. (1998) Mainstreaming Equality in the European Union. London: Routledge.

Reskin, B. and Roos, P. (1990) Job Queues, Gender Queues: Explaining Inroads into Male Occupations. Philadelphia, PA: Temple University Press.

Riska, E. and Wegar, K. (eds) (1993) Gender, Work and Medicine. London: Sage.

Rossiter, M. (1982) Women Scientists in America: Struggles and Strategies to 1940. Baltimore, MD: Johns Hopkins University Press.

Rossiter, M. (1995) Women Scientists in America: Before Affirmative Action 1940-1972. Baltimore, MD: Johns Hopkins University Press.

Schultz, U. and Shaw, G. (eds) (2003) Women in the World's Legal Professions. Oxford: Hart.

UNESCO (1997) International Standard Classification of Education, ISCED 1997. Paris: UNESCO.

Witz, A. (1992) Professions and Patriarchy. London: Routledge.

\section{JUDITH GLOVER is Professor of Employment Studies and Assistant Dean (Research) in the School of Business and Social Sciences at Roehampton University.}

ADDRESS: School of Business and Social Sciences, Roehampton University, 80 Roehampton Lane, London SW15 5SL, UK.

[e-mail: j.glover@roehampton.ac.uk] 